\title{
A Cause Analysis of the High-Content Nitrogen and Low-Content Hydrocarbon in Shale Gas: A Case Study of the Early Cambrian in Xiuwu Basin, Yangtze Region
}

\author{
Yizhou Huang $\mathbb{D})^{1,2}$ Kun Zhang $\mathbb{D}^{1,2,3,4,5}$ Zhenxue Jiang $\mathbb{D}^{1,2}$ Yan Song $\mathbb{D}{ }^{1,2,4}$ \\ Shu Jiang $\odot{ }^{5,6,7}$ Chengzao Jia, ${ }^{4}$ Weiwei Liu, ${ }^{8}$ Ming Wen $\left({ }^{1,},{ }^{1,2}\right.$ Xuelian Xie, ${ }^{9}$ Tianlin Liu, ${ }^{1,2}$ \\ Xin Li, ${ }^{1,2,3}$ Xin Wang, ${ }^{1,2}$ Xiaoxue Liu, ${ }^{1,2}$ Ye Zhang, ${ }^{10}$ and Ling Tang ${ }^{1,2,3}$ \\ ${ }^{1}$ State Key Laboratory of Petroleum Resources and Prospecting, China University of Petroleum, Beijing 102249, China \\ ${ }^{2}$ Unconventional Natural Gas Institute, China University of Petroleum, Beijing 102249, China \\ ${ }^{3}$ Unconventional Petroleum Collaborative Innovation Center, China University of Petroleum, Beijing 102249, China \\ ${ }^{4}$ Research Institute of Petroleum Exploration and Development, Beijing 100083, China \\ ${ }^{5}$ Key Laboratory of Tectonics and Petroleum Resources of Ministry of Education, Faculty of Earth Resources, China University \\ of Geosciences, Wuhan 430074, China \\ ${ }^{6}$ Research Institute of Unconventional Oil \& Gas and Renewable Energy, China University of Petroleum (East China), \\ Qingdao 266580, China \\ ${ }^{7}$ Energy and Geoscience Institute, University of Utah, Salt Lake City, Utah 84108, USA \\ ${ }^{8}$ Jiangxi Provincial Natural Gas Company Ltd., Nanchang 330000, China \\ ${ }^{9}$ Guangzhou Marine Geological Survey, Guangzhou 510760, China \\ ${ }^{10}$ National and Local Joint Engineering Research Center of Shale Gas Exploration and Development, Chongqing Institute of Geology \\ and Mineral Resources, Chongqing 400042, China
}

Correspondence should be addressed to Zhenxue Jiang; zhenxuejiangedu@126.com, Yan Song; yansongpetrochina@126.com, and Shu Jiang; jiangsu@cug.edu.cn

Yizhou Huang and Kun Zhang contributed equally to this work.

Received 29 November 2018; Accepted 27 January 2019; Published 12 June 2019

Guest Editor: Giorgio Minelli

Copyright (C) 2019 Yizhou Huang et al. This is an open access article distributed under the Creative Commons Attribution License, which permits unrestricted use, distribution, and reproduction in any medium, provided the original work is properly cited.

There are successes and failures in the exploration of marine shale gas in South China. In some shale gas plays with great basis for hydrocarbon generation, a phenomenon exists that gas loggings reflect low gas bearing in some of the wells and the gas is dominated by nitrogen rather than hydrocarbon gas. The study of nitrogen concentration in shale gas contributes to solve the question that how shale gas diffuses in complex tectonic areas, which helps to figure out the preservation requirements and accumulation mechanisms of shale gas and avoid exploration crisis. This study focused on the lower Cambrian shale in Xiuwu Basin, Lower Yangtze Region, with emphasis on the well Jiangye-1, using gas component analysis, stable nitrogen isotope analysis, overburden permeability tests in parallel and perpendicular directions, and FIB-HIM experiments, also combining with core description, outcrop observation, and seismic interpretation to explore the causes of the high-content nitrogen and low-content hydrocarbon in the lower Cambrian shale gas. The results show that the nitrogen of the lower Cambrian shale in Xiuwu Basin is derived from the atmosphere and the deep crust-upper mantle. The bedding planes and the detachment layer at the bottom of the lower Cambrian compose the lateral pathways, and the widespread deep faults are the vertical pathways for shale gas migration and diffusion. Combining these two, an effective pathway network was built, favorable to gas exchange between the shale gas interval and the atmosphere, partly leading to the concentration of nitrogen and the diffusion of 
hydrocarbon gas. In the Jurassic, the magmatic activities occurred frequently in the surrounding areas, which not only brought nitrogen from the deep crust-upper mantle but also increased the value of paleo-heat flow even though the basin began to uplift, which promoted the graphitization of organic matter and the collapse of organic pores and accelerated the loss of shale gas. Based on the study above, an explanation model was summarized to expound the causes of high-content nitrogen and low-content hydrocarbon in shale gas plays near the plate-active region in Xiuwu Basin, Lower Yangtze Region.

\section{Introduction}

In recent years, because of the progress in geological theories and hydraulic fracturing technology, shale gas has drawn an increasing attention of exploration and development of oil and gas all over the world [1-3]. In China, since 2010, the well Wei-201 in Weiyuan Structure realized the industrialization of shale gas resources. Until 2018, shale gas plays like Weiyuan, Changning, Fushun-Yongchuan, Jiaoshiba, and Dingshan were continually established to achieve large-scale exploration and exploitation [4, 5]. Although successes are achieved, failures still exist that the gas content varies dramatically depends on plays [6, 7]. This makes further study on shale gas accumulation mechanism urgent to be carried out $[8,9]$. Explorations on the accumulation mechanisms of shale gas have been carried out by previous works, including shale heterogeneity [10-12], shale pore connectivity [13-16], shale sedimentary environments [17], and structural styles $[18,19]$. However, compared with North America, the Paleozoic marine shale in South China experienced a more complex, multistage tectonic and thermal evolution. Although the plays were equipped with similar materials basis, such as the similar total organic carbon (TOC) content and mineral composition, the gas-bearing properties are diverse under different preservation conditions. Thus, accurate selections of favorable intervals and areas are important for shale gas exploration [20].

Methods have been applied to previous studies about preservation conditions of shale gas. Cheng et al. [21] researched shale gas preservation conditions of the lower Cambrian Niutitang formation in the Enshi-Lichuan Play. From material basis, tectonic effects, and evolution history, they proposed a comprehensive evaluation index system of shale gas preservation. Guo et al. [22] put forward "accumulation controlling production" theory which considered preservation conditions crucial for shale gas accumulation. Quality roof and floor effectively prevent hydrocarbon from diffusing vertically and strand hydrocarbon right after its generation. The strength and duration of tectonic effects determine the preservation conditions, which are key geological factors in the theory. A shale reservoir, with quality gas-bearing properties, large porosity, and high formation pressure, is inclined to be a prolific area enriched by natural gas. Zhai et al. [23] demonstrated the main controlling factors of production of marine shale gas reservoir in South China which include quality organic-rich shale deposited in deep-water shelf (favorable for hydrocarbon generation) and appropriate tectonic uplift time and structural styles (keys of shale gas accumulation and preservation). They summarized three major types of shale gas structural styles: the complete, the residual, and the destructive styles. Also, overpressure is considered as a necessary prerequisite for high production.
Many shale gas plays of the lower Cambrian located outside the Sichuan Basin, represented by Xiuwu Basin, are blessed with great material basis but no considerable commercial discoveries, only slightly gas bore. Among the wells, a phenomenon is shown in common that the nitrogen content is distinguished, reflecting the complexity of the preservation conditions of shale gas in the lower Cambrian [24-29]. Since nitrogen is an indicator, directly reflecting the preservation conditions of oil and gas plays, the study of nitrogen in shale gas promotes the clarification of the preservation regulations and shale gas accumulation mechanism [3033], which are important for accurately selecting favorable intervals and areas and avoiding crisis during the shale gas exploitation.

Therefore, based on the detailed components of the lower Cambrian shale gas, this paper combined stable nitrogen isotopes and previous works to determine the sources of nitrogen and then figured out the causes of high-content nitrogen and low-content hydrocarbon in the lower Cambrian shale gas by the comprehensive analysis of regional geological settings, tectonic characteristics, and thermal evolution history. Finally, a shale gas accumulation model was established to explain the causes, significant to the exploration and exploitation of shale gas in highly matured shale in complex tectonic zones.

\section{Geological Settings}

2.1. Tectonic and Sedimentary Characteristics. The study area is located in Xiuwu Basin, Lower Yangtze Region (Figure 1). Xiuwu Basin was a stable cratonic basin in the Cryogenian and then experienced a regression in the late Cryogenian, when the Piyuancun formation was deposited. A massive transgression occurred in the early Cambrian, leading to the deposition of the Wangyinpu formation in a deep-water basin (Figure 2), which is a set of black organic-rich siliceous shale of 45-60 m thick. Afterwards, the seawater was gradually shallower and the upper part of the Guanyintang formation formed in shallow-water shelf facies [34]. Subsequently, the sedimentary environments transformed from a clastic sedimentary system in early Cambrian to a carbonate system in the middle-late Cambrian and further to a detrital sedimentary system in the early-middle Ordovician [35]. In the late Ordovician-early Silurian, due to the plate collision, the study area changed to a deep-water basin when the Xinkailing-Lishuwo shale was deposited. Since the middle Silurian, the seawater became shallower and the study area began to uplift to ancient lands in the late Silurian $[36,37]$. In the Devonian-Carboniferous, sedimentation and uplift interlaced with little deposition. The Permian and the early-middle Triassic welcomed another major sedimentary period. The late Triassic was affected by the collision 


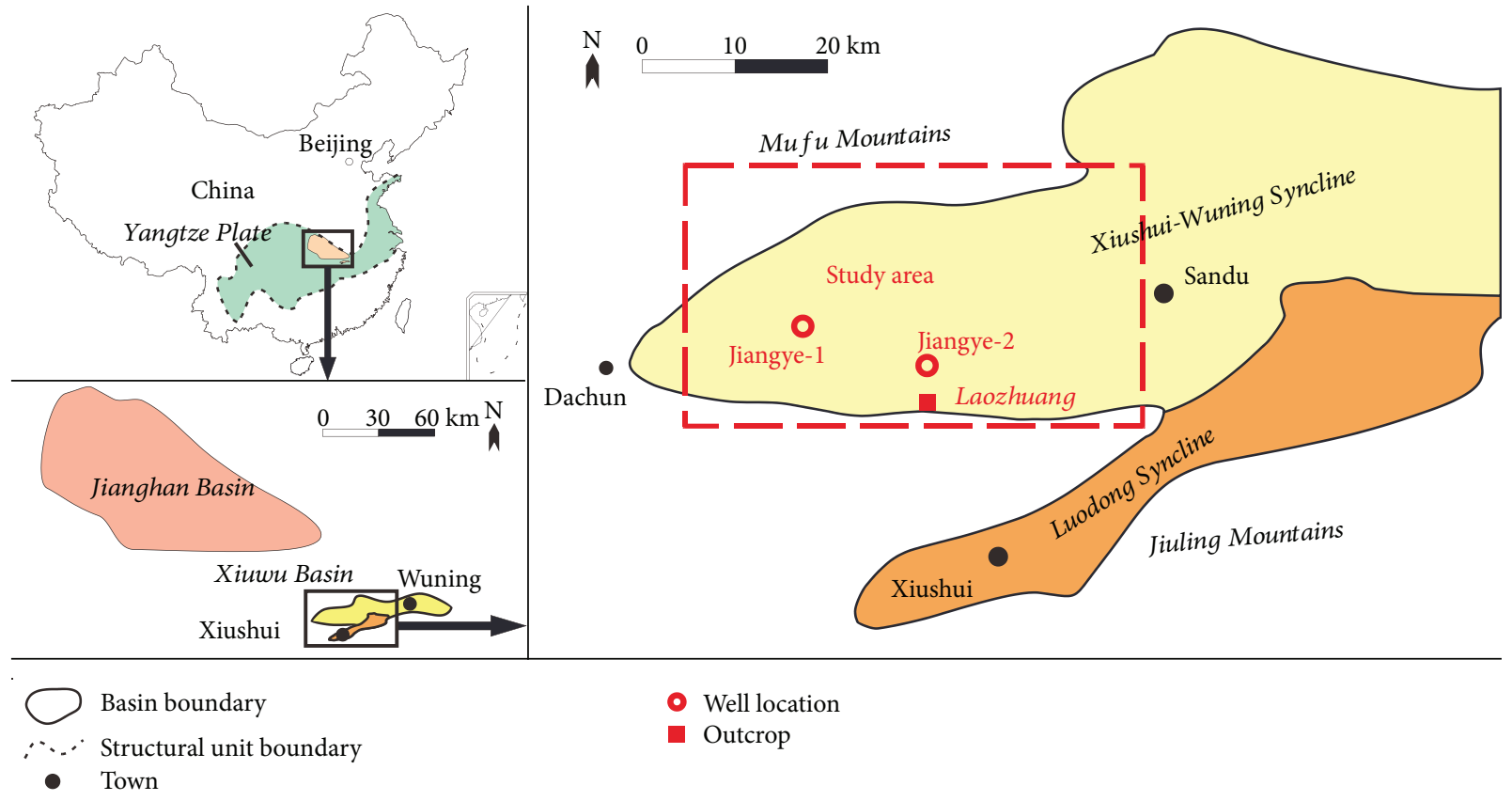

Figure 1: Locations of the study area and wells and outcrop mentioned.

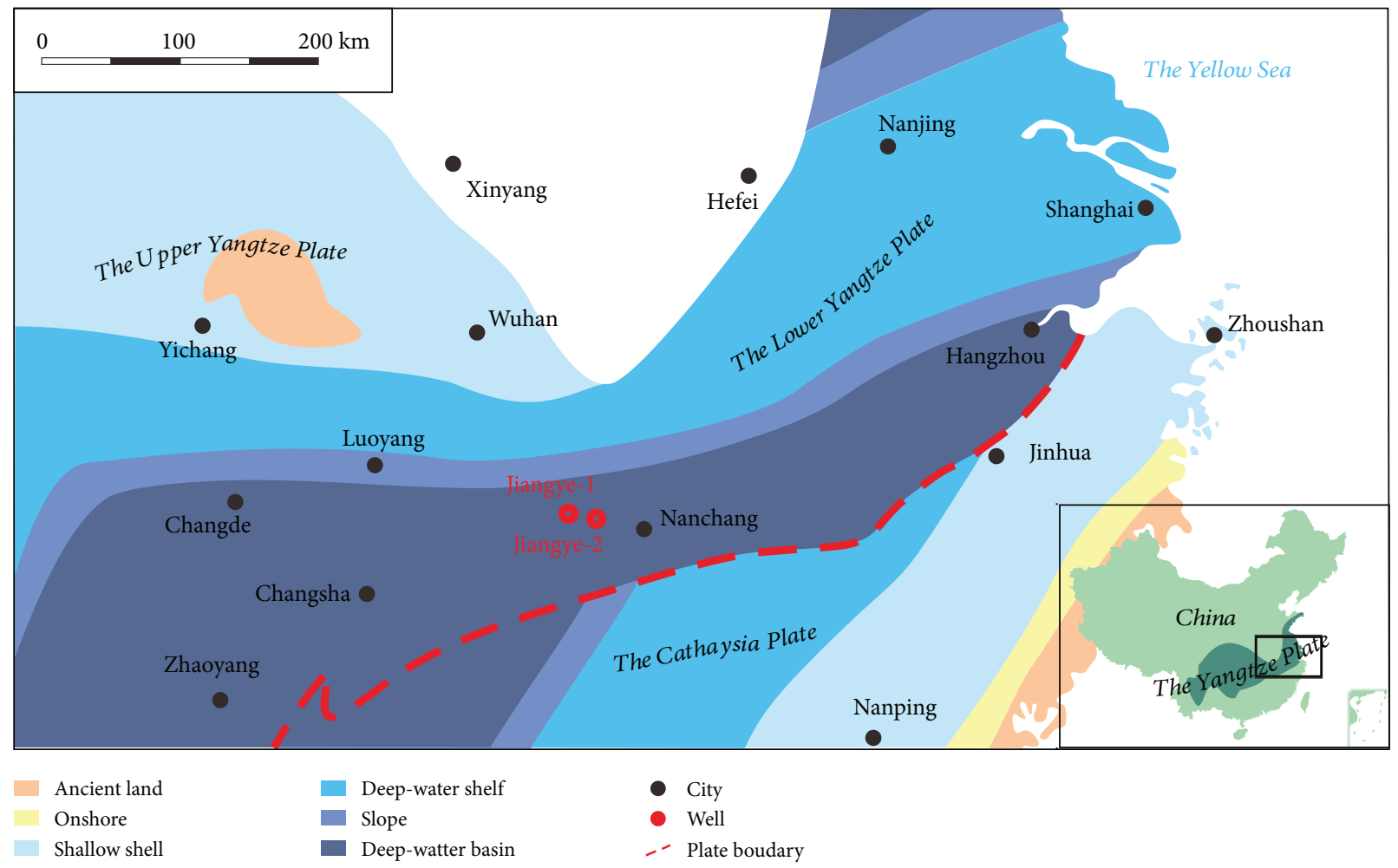

FIgURe 2: A map of the regional sedimentary characteristics of the lower Cambrian in the Lower Yangtze, South China.

between the North China and the Southern China plates; thus, the study area was uplifted [27, 38] and ended up a syncline with lots of thrust faults in the early-middle Jurassic by extrusion [39].
2.2. Stratigraphic Characteristic. The research target is the lower Cambrian Wangyinpu and Guanyintang formations. Wangyinpu formation is underlain by the late Ediacaran Piyuancun formation, which is dominated by gray siliceous 


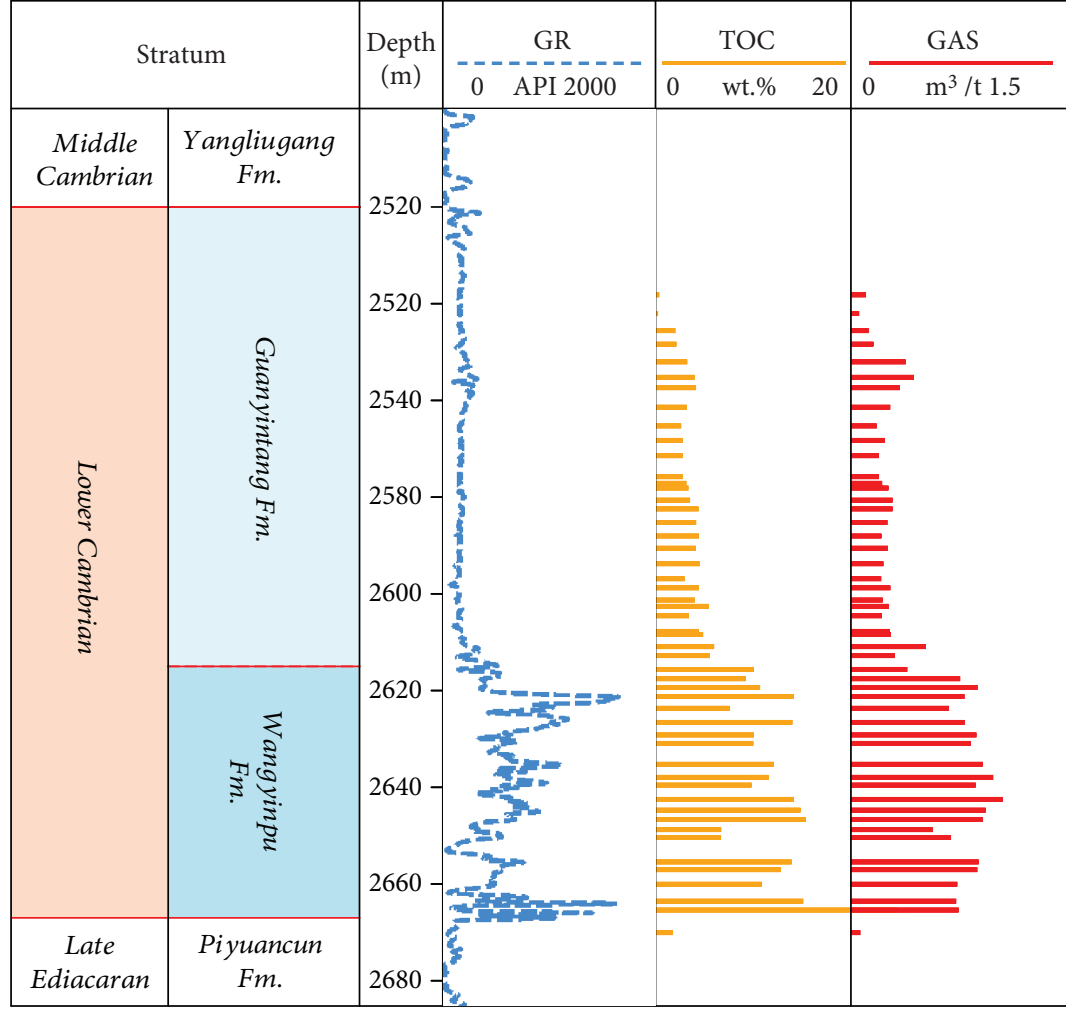

(a)
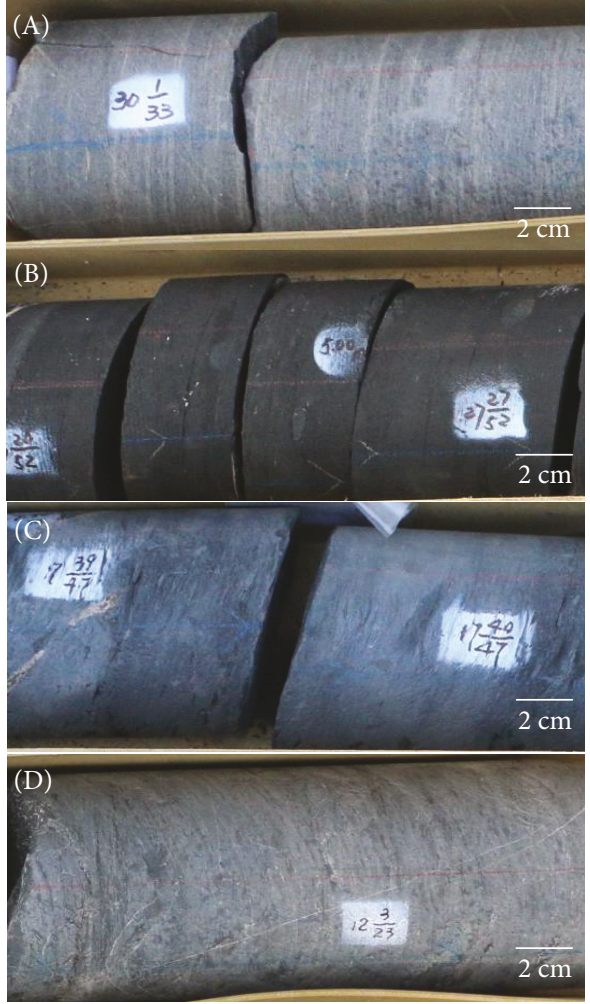

(b)

FIgURE 3: A stratigraphic column and core photos of the late Ediacaran and the lower-middle Cambrian of Jiangye-1. (A) The late Ediacaran Piyuancun formation (depth: $2675 \mathrm{~m}$ ). (B) The lower Cambrian Wangyinpu formation (depth: $2638 \mathrm{~m}$ ). (C) The lower Cambrian Guanyintang formation (depth: $2546 \mathrm{~m}$ ). (D) The middle Cambrian Yangliugang formation (depth: $2511 \mathrm{~m}$ ). The data of gamma ray log and total gas content were from Schlumberger. See Figure 1 for the well location. Fm. = formation; GR=gamma ray log; TOC=total organic carbon content; GAS = total gas content.

dolomite. The Wangyinpu formation is black siliceous shale, and Guanyintang formation is dark gray siliceous shale. Guanyintang formation is the middle Cambrian Yangliugang formation, a set of gray micrite limestone (Figure 3(b)). These strata are all conformly contacted.

2.3. Present Conditions of Exploration. According to the exploration history, there are two shale gas wells named Jiangye-1 and Jiangye-2 (Figure 1). The lower Cambrian shale of Jiangye- 1 is around $58 \mathrm{~m}$ thick and equipped with sapropel-type kerogen. The TOC content is generally larger than $2 \mathrm{wt} \%$ (Figure $3(\mathrm{a})$ ), and the average porosity is about $2.1 \%$. Based on the previous study of storage potential, the theoretical gas content of the lower Cambrian shale is $2.29-5.73 \mathrm{~m}^{3} / \mathrm{t}$. Therefore, it tells that the study area is theoretically favorable for hydrocarbon generation.

However, the gas logging of Jiangye-1 reflects a weak gas bearing with a decreasing downwards gas content of $0.01-1.23 \mathrm{~m}^{3} / \mathrm{t}$ (Figure 3(a)) and the adsorbed gas on field of Jiangye- 2 is dominated by nitrogen. This contrast leads to the target problem of this paper why there is high-content nitrogen rather than hydrocarbon gas in the shale gas in an area theoretically favorable for hydrocarbon generation.

\section{Methodology}

3.1. TOC Content Test and Gas Content Test. From the lower Cambrian shale in Jiangye-1, fifty-one core samples were selected in total. Present-day TOC content tests were carried out by an OG-2000v analyzer and gas content tests were operated by LH-2 shale gas content analyzer.

3.2. Gas Component Analysis and Nitrogen Isotope Analysis. Using the AD-RJ-150-6-type shale gas field analytical instrument, there are sixteen gas samples of different depths collected from the cores of the lower Cambrian Guanyintang and Wangyinpu formations in Jiangye-1 (Table 1). The cores were taken on field. The gas samples underwent gas component analysis by the GC-2014C Gas Chromatograph and stable nitrogen isotope analysis by the EA IsoLink ${ }^{\mathrm{TM}} 253$ Plus $^{\mathrm{TM}}$ IRMS.

3.3. Overburden Permeability Test. From the lower Cambrian Wangyinpu formation in the Lower Yangtze, there were ten samples selected, among which 2 were from Jiangye- 1 and the other 8 were from Jiangye-2 (Table 2). The overburden permeability analyzer PDP-200 was adopted in the tests in both directions of parallel (for lateral permeability) and perpendicular (for vertical permeability) to bedding planes. The 
TABLE 1: Information of gas samples from Jiangye-1. See Figure 1 for the well location.

\begin{tabular}{lccc}
\hline No. & Well & Depth $(\mathrm{m})$ & Fm. \\
\hline 1 & Jiangye-1 & 2540 & Guanyintang \\
2 & Jiangye-1 & 2545 & Guanyintang \\
3 & Jiangye-1 & 2562 & Guanyintang \\
4 & Jiangye-1 & 2568 & Guanyintang \\
5 & Jiangye-1 & 2574 & Guanyintang \\
6 & Jiangye-1 & 2580 & Guanyintang \\
7 & Jiangye-1 & 2585 & Guanyintang \\
8 & Jiangye-1 & 2590 & Guanyintang \\
9 & Jiangye-1 & 2595 & Guanyintang \\
10 & Jiangye-1 & 2602 & Guanyintang \\
11 & Jiangye-1 & 2612 & Wangyinpu \\
12 & Jiangye-1 & 2620 & Wangyinpu \\
13 & Jiangye-1 & 2635 & Wangyinpu \\
14 & Jiangye-1 & 2641 & Wangyinpu \\
15 & Jiangye-1 & 2655 & Wangyinpu \\
16 & Jiangye-1 & 2669 & Wangyinpu \\
\hline
\end{tabular}

No. $=$ sample number; Fm. $=$ formation.

TABLE 2: Information of samples for permeability tests. See Figure 1 for the well locations.

\begin{tabular}{lccc}
\hline No. & Well & Depth $(\mathrm{m})$ & Fm. \\
\hline 1 & Jiangye-1 & 2635 & Wangyinpu \\
2 & Jiangye-1 & 2641 & Wangyinpu \\
3 & Jiangye-2 & 3090 & Wangyinpu \\
4 & Jiangye-2 & 3095 & Wangyinpu \\
5 & Jiangye-2 & 3101 & Wangyinpu \\
6 & Jiangye-2 & 3108 & Wangyinpu \\
7 & Jiangye-2 & 3115 & Wangyinpu \\
8 & Jiangye-2 & 3122 & Wangyinpu \\
9 & Jiangye-2 & 3129 & Wangyinpu \\
10 & Jiangye-2 & 3135 & Wangyinpu \\
\hline
\end{tabular}

No. = sample number; Fm. = formation.

pressure of the permeability test and the confining pressure was 1000 and 1500 psi, respectively.

3.4. FIB-HIM Experiment. FIB-HIM is suitable for shale micropore reorganization for its high resolution, which makes it possible to achieve a resolution of $0.5 \mathrm{~nm}$ under $45 \mathrm{kV}$. An ORION NanoFab microscope is used to identify organic pores. Additionally, grinding and Ar-ion polishing were involved in a sample preparation.

In this paper, samples were chosen from the organic-rich shale of the lower Cambrian Wangyinpu formation in Jiangye- 1 at a depth of $2630 \mathrm{~m}$. The data of the experimental results of the lower Silurian Longmaxi formation shale of the Jiaoye-1 in Sichuan Basin, South China, were from Wang et al. $[13,14,40]$.

\section{Results and Discussion}

4.1. Gas Components. The results of gas components analysis are shown in Figure 4. It supposes that the shale gas is dominated by nitrogen and oxygen with the percentage of volume of $80 \%$ and $17 \%$, respectively, which is close to the content in the air ( $78 \%$ and $21 \%$, respectively). The average methane content is only $0.22 \%$.

In comparison, the average nitrogen content in natural gas is about 3\% in the United States and less than $8 \%$ in most plays of China [30]. The nitrogen content is $10 \%$ 30\% in natural gas of the Tarim Basin, where nitrogen is highly concentrated [31,33], less than $10 \%$ in Northeast Chongqing shale gas and almost 0 in Jiaoshiba shale gas play, Fuling [28, 30, 32 . The nitrogen content of the study area is far higher than average and reflects its unique accumulation characteristics.

4.2. Nitrogen Sources. From the tests of stable nitrogen isotope, the $\delta^{15} \mathrm{~N}$ of all the sixteen samples ranges from $-0.8 \%$ o to $0 \%$ (Figure 5). It is summarized from the previous researches that the content of stable nitrogen isotope depends on its sources, and based on Krooss et al. [41], Zeng [42], and Liu et al. [43], nitrogen sources, genesis mechanisms, and corresponding isotopic content are summarized in Table 3. The $\delta^{15} \mathrm{~N}$ of the study area falls in two sources. Therefore, it indicates the mixed origins of nitrogen, the atmosphere, and the deep crust-upper mantle.

\subsection{Causes of Nitrogen Concentration}

\subsubsection{Effective Pathway Network to Atmosphere}

(1) Lateral Pathway. In the overburden permeability tests, the lateral permeability and the vertical permeability were obtained by samples being tested in parallel and perpendicular, respectively, to the bedding planes. As Figure 6 shows, generally, the lateral is larger than the vertical and the ratio of these two reflects that the lateral permeability is more than 1 40 times higher than the vertical, indicating a dominant migration pathway along the bedding planes (Figure 7).

Cores were from the bottom of the lower Cambrian shale in Jiangye- 1 and Jiangye-2. The observation revealed obvious characteristics of the bedding slip deformation (Figures 8(a) and $8(\mathrm{~b})$ ). Furthermore, apparent slippage and crinkle phenomenon (Figure 8(c)) are presented in the Laozhuang Outcrop. These obvious deformation structures are widely developed at the bottom of the Wangyinpu formation in the study area, reflecting the general existence of a detachment layer at the bottom of the lower Cambrian in Xiuwu Basin, which resulted from the relative slipping between the soft shales of the Wangyinpu formation and the hard siliceous dolomite of Piyuancun formation under the North-South extrusion influencing the whole basin. The gas content of the Wangyinpu formation decreased when it is near the bottom, from $0.93 \mathrm{~m}^{3} / \mathrm{t}$ in the lower part to $0.73 \mathrm{~m}^{3} / \mathrm{t}$ at the bottom of the formation. The detachment layer at the bottom of the lower Cambrian greatly accelerated the diffusion process of shale gas. 


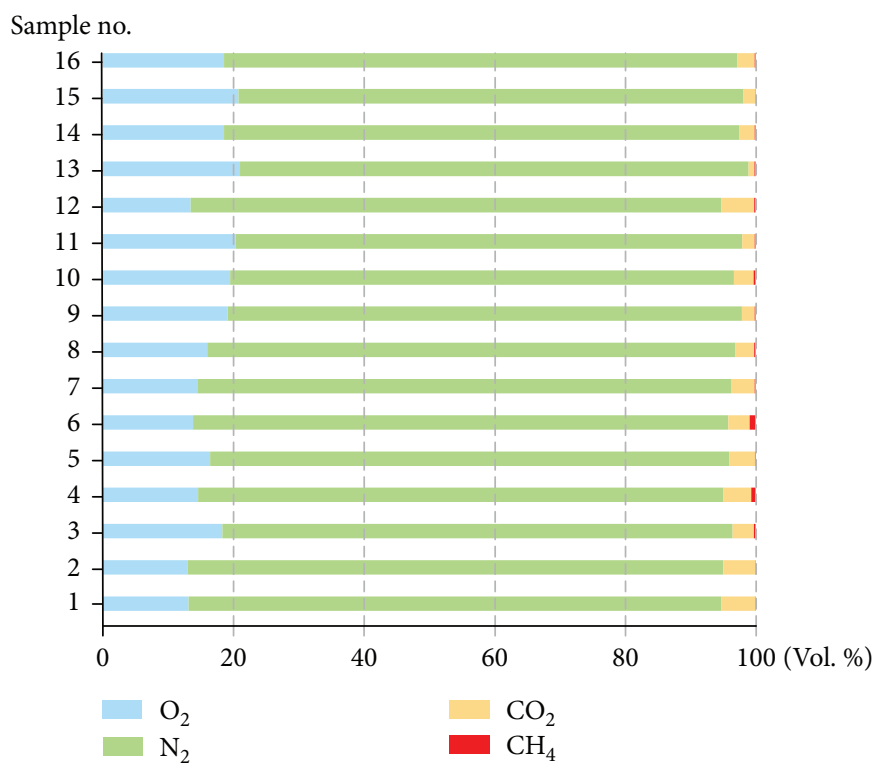

FIGURE 4: Gas components of the lower Cambrian Guanyintang and Wangyinpu formations of Jiangye-1. See Figure 1 for the location of the well location.

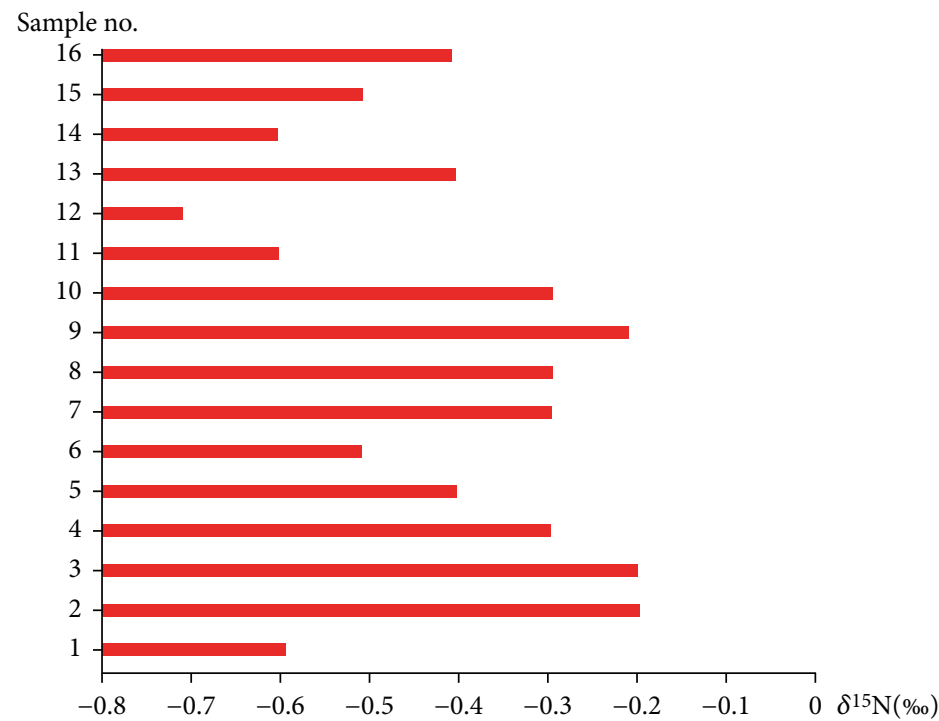

FIgURE 5: $\delta^{15} \mathrm{~N}$ content of the lower Cambrian Guanyintang and Wangyinpu formation shale gas of Jiangye-1. See Figure 1 for the location of the well location.

TABLE 3: Summarized characteristics of stable nitrogen isotope of nitrogen in natural gas of different sources (modified from Zeng [42] and Liu et al. [43]).

\begin{tabular}{|c|c|c|c|c|}
\hline \multicolumn{2}{|l|}{ Sources } & \multicolumn{2}{|c|}{ Genesis mechanism } & Nitrogen isotope $\left(\delta^{15} \mathrm{~N} \approx\right)$ \\
\hline \multicolumn{2}{|l|}{ Atmosphere } & \multicolumn{2}{|c|}{ Carried by surface water, diffused underground } & $0 \%$ \\
\hline \multicolumn{2}{|c|}{ Deep crust-upper mantle } & \multicolumn{2}{|c|}{ Thermal reactions and radiation effects in the Earth's core } & $-2 \% \sim+1 \%$ \\
\hline \multirow{5}{*}{ Sedimentation } & Metamorphism & \multicolumn{2}{|c|}{ High temperature metamorphism of nitrogenous minerals } & $+1 \% 0 \sim+3.5 \%$ o \\
\hline & Microbial denitrification & \multicolumn{2}{|c|}{$\begin{array}{c}\text { Generated by interactions between organisms and } \\
\text { organic matter }\end{array}$} & $-17 \%$ - $10 \%$ \\
\hline & \multirow{3}{*}{ Thermal evolution } & \multirow{3}{*}{ Evolutionary stages of organic matter } & Immature & $<-10 \%$ \\
\hline & & & Mature-highly mature & $-10 \%$ - $1 \%$ o \\
\hline & & & Overmature & $+5 \%$ $+20 \%$ \\
\hline
\end{tabular}




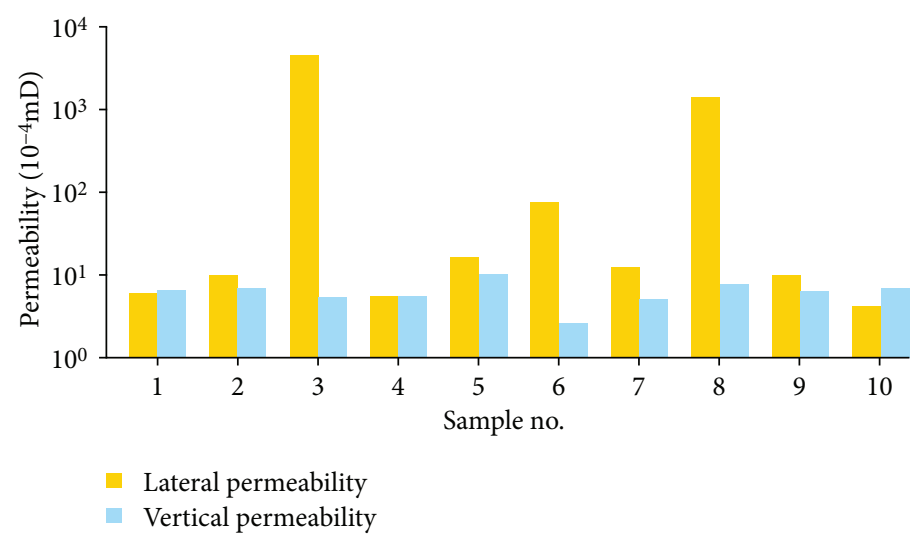

Figure 6: Lateral and vertical permeability of the lower Cambrian shale of Jiangye-1 and Jiangye-2. See Figure 1 for the well locations.

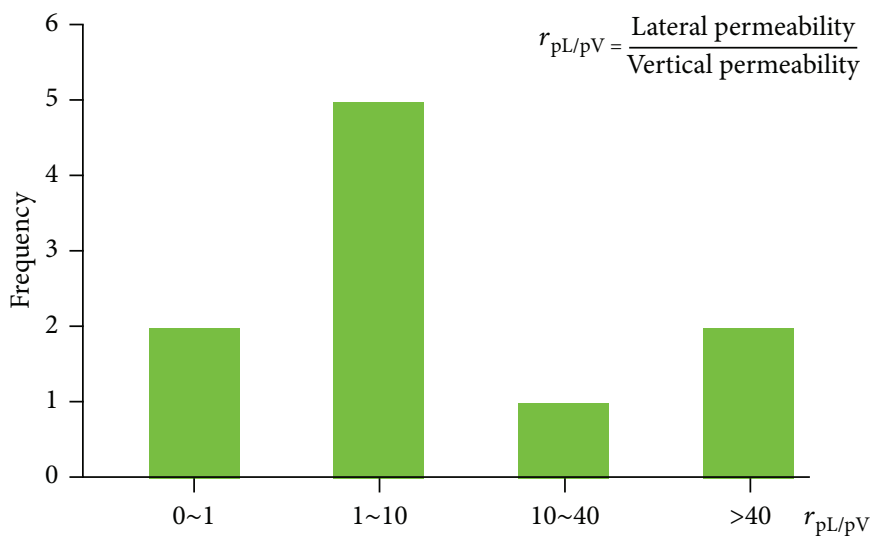

FIGURE 7: The ratio of lateral and vertical permeability of the lower Cambrian of Jiangye-1 and Jiangye-2. See Figure 1 for the well locations.

From the analysis above, the bedding surface and the detachment layer comprise the migration pathways in the lateral direction to communicate with the atmosphere, partly leading to the concentration of nitrogen and the diffusion of hydrocarbon gas.

(2) Vertical Pathway. Physical sealing is the main mechanism that roof and floor seal the natural gas within organic-rich shale in vertical direction. A quality seal on organic-rich shale requires a large thickness of roof and floor and a lower porosity than shale gas interval. The burial depth, the thickness of the organic-rich shale, and the average TOC content control the self-sealing property of the shale. As Table 4 tells, the roof of Guangyintang formation and the floor of Piyuancun formation are equipped with a large thickness and much lower porosity than the shale gas interval. In the meanwhile, the shale gas interval of Wangyinpu formation is buried at a moderate depth (2609.5 2672 m) with a large thickness of organic-rich shale $(62.5 \mathrm{~m})$. Its TOC content is higher than the roof and the floor reflecting a stronger adsorption capability of shale gas and a strong self-sealing property. Therefore, it reveals that the lower Cambrian shale should have a favorable physical sealing.

However, things changed when it comes to the tectonic evolution and seismic interpretation.
As mentioned in geological settings, tectonic evolution history shows that, influenced by the collision between the Southern China and the North China plates, study area was squeezed into a syncline with a large number of thrust faults in the early-middle Jurassic [39]. After that, in the Late Cretaceous to the Paleogene, the stress of the whole basin changed from extrusion to tension forcing the faults reopened due to the tension effects from the subduction of the Pacific Plate to the Eurasian Plate [44]. The stress did not change back to extrusion from tension until the Neogene $[13,14]$.

According to the seismic inter of the section through the study area, deep and large faults developed massively going through the roof, the shale gas interval, and even the floor (Figure 9). These faults destroyed the physical sealing in vertical direction, forming the vertical pathways, composing the pathway network with the lateral ones and made it more effective for gas exchange with the atmosphere. Furthermore, the reopening of the faults in Late Cretaceous to the Paleogene contributes to a large loss of shale gas.

4.3.2. Frequent Magmatic Activities Brought Nitrogen. According to the previous studies [45], the value of paleo-heat flow changed greatly since the early Cambrian. The value of paleo-heat flows increased slowly at first (the Cambrian to the Late Triassic: $543 \mathrm{Ma} 205 \mathrm{Ma}$ ) and then 


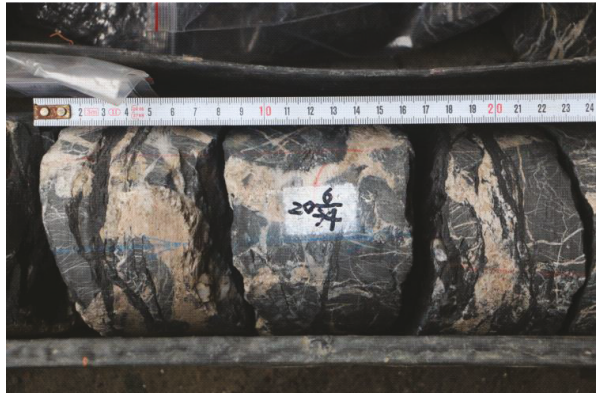

(a)

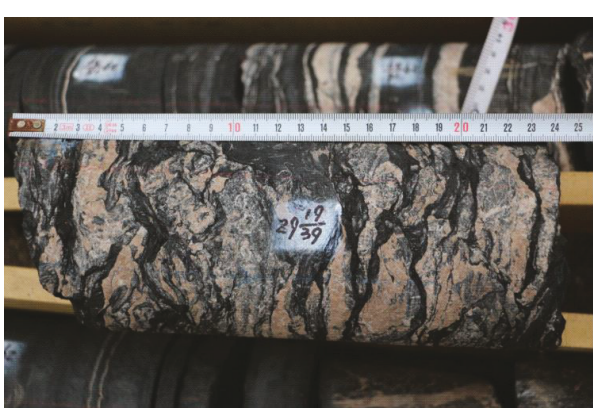

(b)

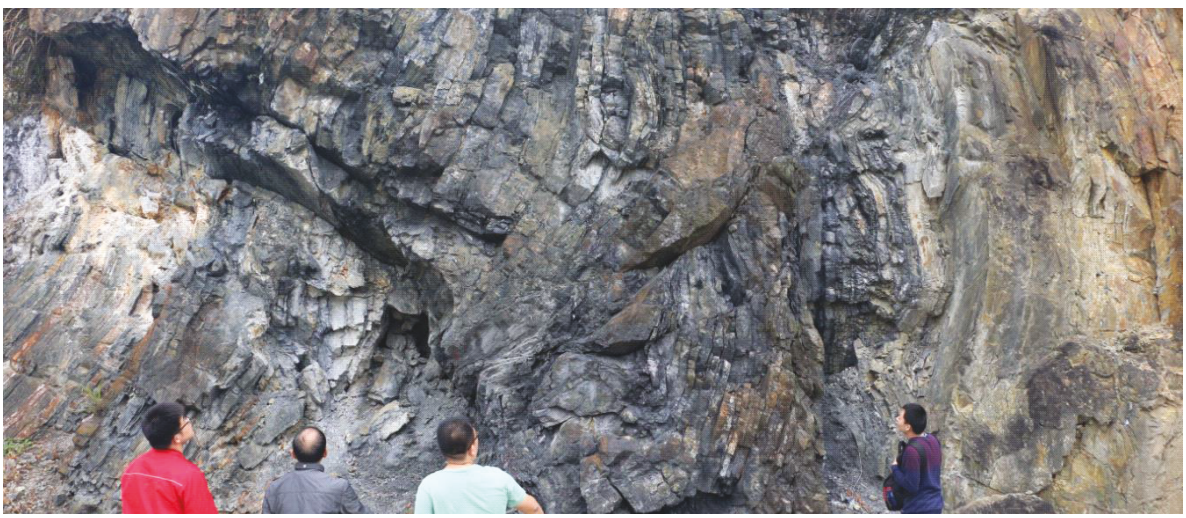

(c)

Figure 8: A detachment layer widely developed at the bottom of the lower Cambrian Wangyinpu formation shale in Xiuwu Basin. Core photos at the bottom of the lower Cambrian Wangyinpu formation: (a) in Jiangye-1 (depth: $2670 \mathrm{~m}$ ) and (b) in Jiangye-2 (depth: $3135 \mathrm{~m}$ ). (c) A photo of Laozhuang Outcrop at the bottom of the lower Cambrian Wangyinpu formation. See Figure 1 for the well locations.

TABLE 4: The sealing parameters of shale and its roof and floor in Jiangye- 1 of the lower Cambrian Wangyinpu formation. The data of average TOC content and average porosity is referred to Liu et al. [24]. See Figure 1 for the well locations.

\begin{tabular}{lcccccc}
\hline Part & Fm. & Lith. & Depth $(\mathrm{m})$ & Avg. TOC (\%) & Avg. porosity (\%) & Thk. (m) \\
\hline Roof & Guanyintang & Silty shale & $2520 \sim 2609.5$ & $2 \sim 4$ & 1.2 & 89.5 \\
Shale gas interval & Wangyinpu & Organic-rich siliceous shale & $2609.5 \sim 2672$ & $7 \sim 14$ & 2.2 & 62.5 \\
Floor & Piyuanchun & Silty shale & $>2672$ & $0.1 \sim 0.6$ & 0.7 & $>50$ \\
\hline
\end{tabular}

Fm. = formation; Lith. = lithology; Avg. = average; TOC = total organic carbon; Thk. = thickness.

began a rapid increase since the Late Triassic (around $205 \mathrm{Ma})$. According to regional tectonic evolution, it was when the plates of the North China and the South China collided leading to frequent magmatic activities in surrounding areas. At the turn of the Jurassic and the Cretaceous (around $137 \mathrm{Ma})$, it reached a maximum. It gradually cooled down during the early Cretaceous (137 Ma 96 Ma). In the Late Cretaceous to the Paleogene (96 Ma 23.3 Ma), it reached another high point due to the tectonic movements (Figure 10). It slowly cooled down to the present value afterwards.

The frequent magmatic activities brought nitrogen from the deep crust and upper mantle to the basin basement. In the process of magma cooling, nitrogen was vaporized into the lower Cambrian shale reservoir.

4.3.3. Overmaturity Accelerated Diffusion. The thermal evolution of organic matter is mainly controlled by paleo-geotemperature, while paleo-geotemperature is related to buried depth and value of paleo-heat flows. According to the previous researches [39, 45-48], Xiuwu Basin reached the maximum burial depth when the North China plate collided with the South China plate in the Triassic. As it can be told from the burial and thermal evolution history (Figure 11), even though it uplifted after reaching the maximum depth, the geotemperatue continued to increase as the value of paleo-heat flows increased rapidly and reached $270^{\circ} \mathrm{C}$ at the turn of the Jurassic and the Cretaceous $(137 \mathrm{Ma})$. The organic matter was consequently overcooked with the vitrinite reflection $\left(R_{\mathrm{o}}\right)$ of $3.8 \%$ and evolved into graphitization stage [45].

Generally, organic pores are more developed in moderate maturity $\left(R_{\mathrm{o}}: 2 \% \sim 3 \%\right)$. The graphitization of organic matter may collapse the organic pores and lead to the decrease of the adsorption capacity of organic matter to natural gas, and, therefore, reducing of gas bearing potential of shale [49-54]. The low-mature Longmaxi shale and the overmature Wangyinpu shale were compared. Figures 12(a) and 12(b) are FIB-HIM photos of the Longmaxi shale in 


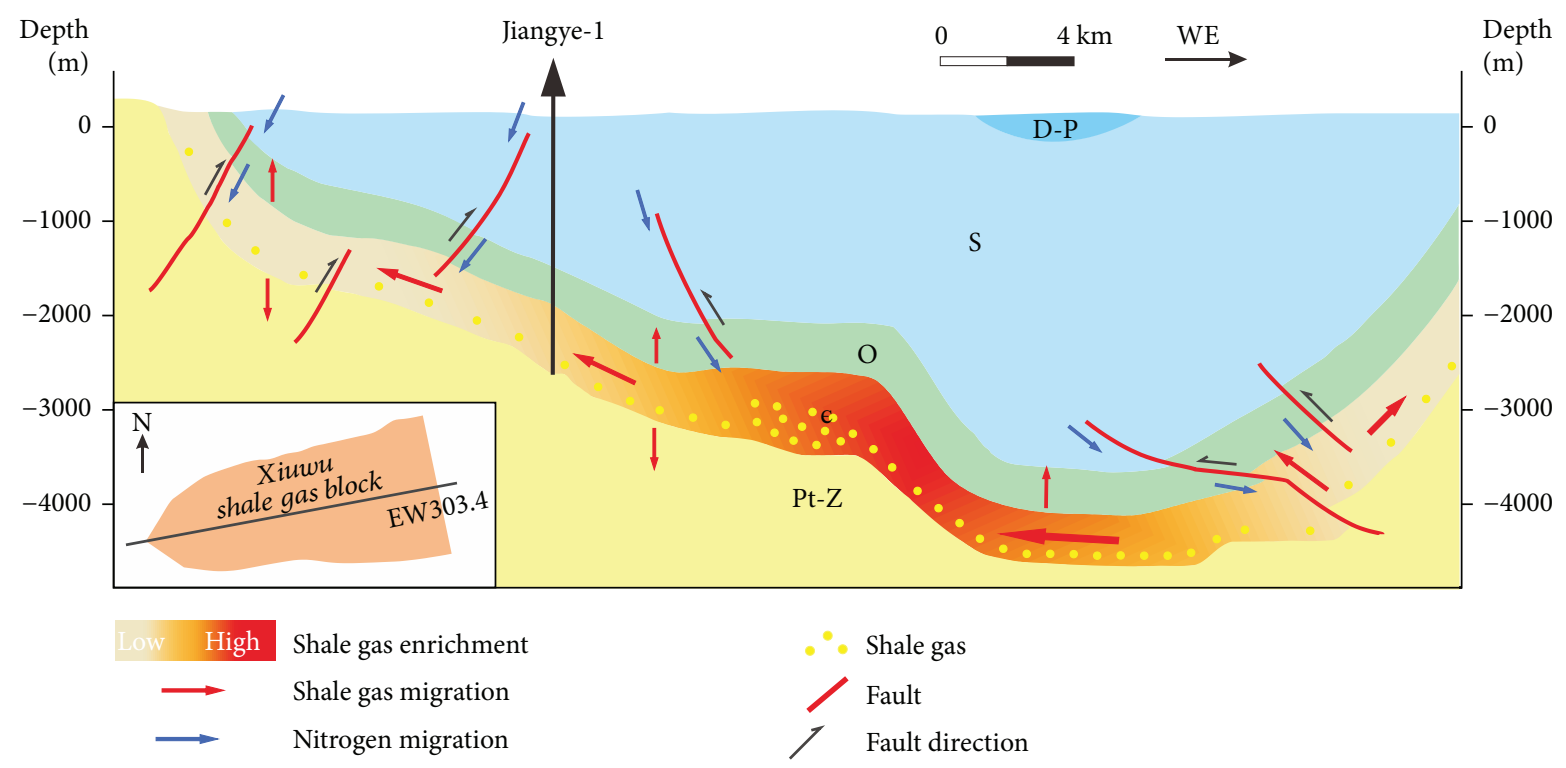

FIGURE 9: Hydrocarbon gas diffuses and nitrogen from atmosphere entrances through bedding planes, the detachment layer, and deep faults in section of EW303.4 through Xiuwu Basin. See Figure 1 for the well locations.

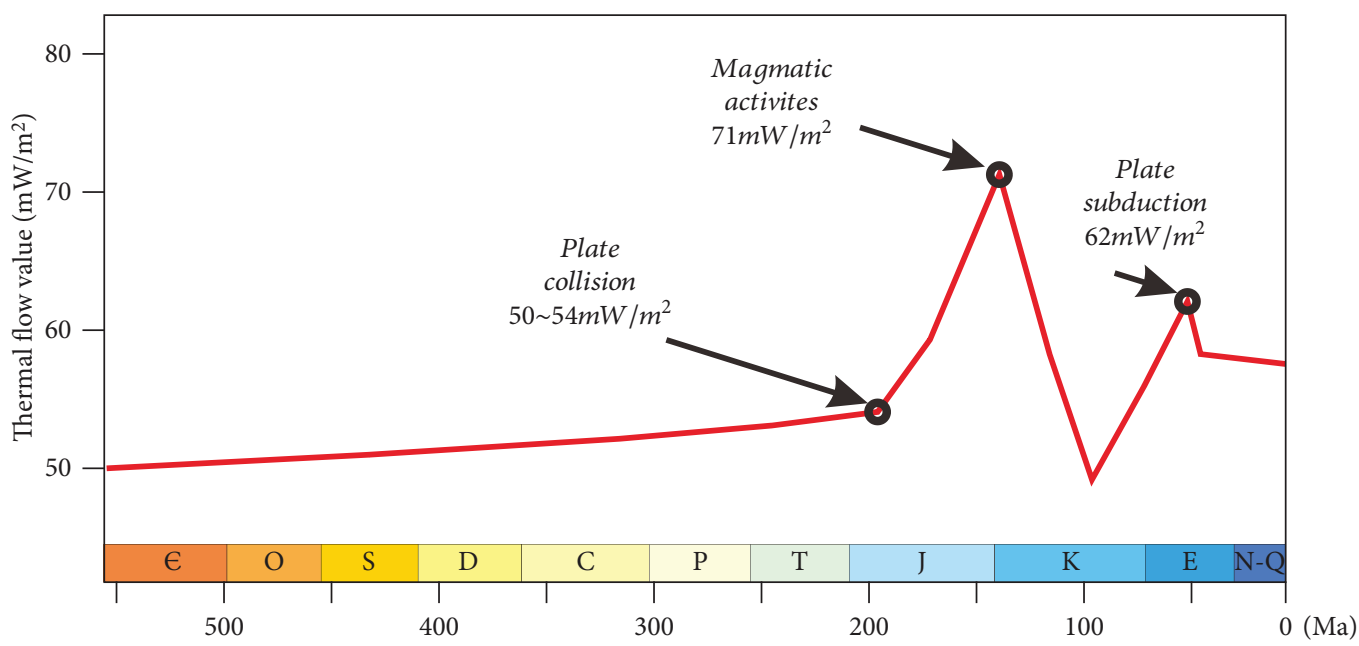

Figure 10: Value of the paleo-heat flows in Xiuwu Basin. Data is referred to Li et al. [45].

Jiaoye- 1 and the Wangyinpu shale in Jiangye-1. It shows much fewer organic pores observed in the Wangyinpu shale. This resulted in the diminishment of storage ability of shale and promoted the loss of hydrocarbon gas and relatively increased the nitrogen content.

4.4. Explanation Model Summarization. After all the studies above, a model was summarized to explain the destruction of shale gas reservoirs and the causes of high-content nitrogen and low-content hydrocarbon in shale gas of the study area, which affected by active plate movements. As presented in Figure 13, the effective network of migration pathways made the gas exchange possible between the shale gas reservoir and the atmosphere. The network is composed of the lateral pathways including the bedding surface and the detachment layer and the vertical ones which are the trust faults. The magmatic activities not only brought the nitrogen from the deep crust and upper mantle but also overcooked the organic matter and accelerated the loss of shale gas, which increased the relative content of nitrogen.

As a shale gas play, which was favorable for hydrocarbon generation but experienced complex tectonic evolution and affected by plate movements, the study area represents areas near the plate conjecture in the Lower Yangtze Region. The summarized model is applicable to explain the causes of the destruction of shale gas reservoirs and the widespread phenomenon where nitrogen concentrates and hydrocarbon diffuses in tectonic-complex areas in the Lower Yangtze Region and even in the some plate-active areas.

\section{Conclusions}

To solve the problem why a general phenomenon exists that nitrogen is highly concentrated and hydrocarbon diffuses in 


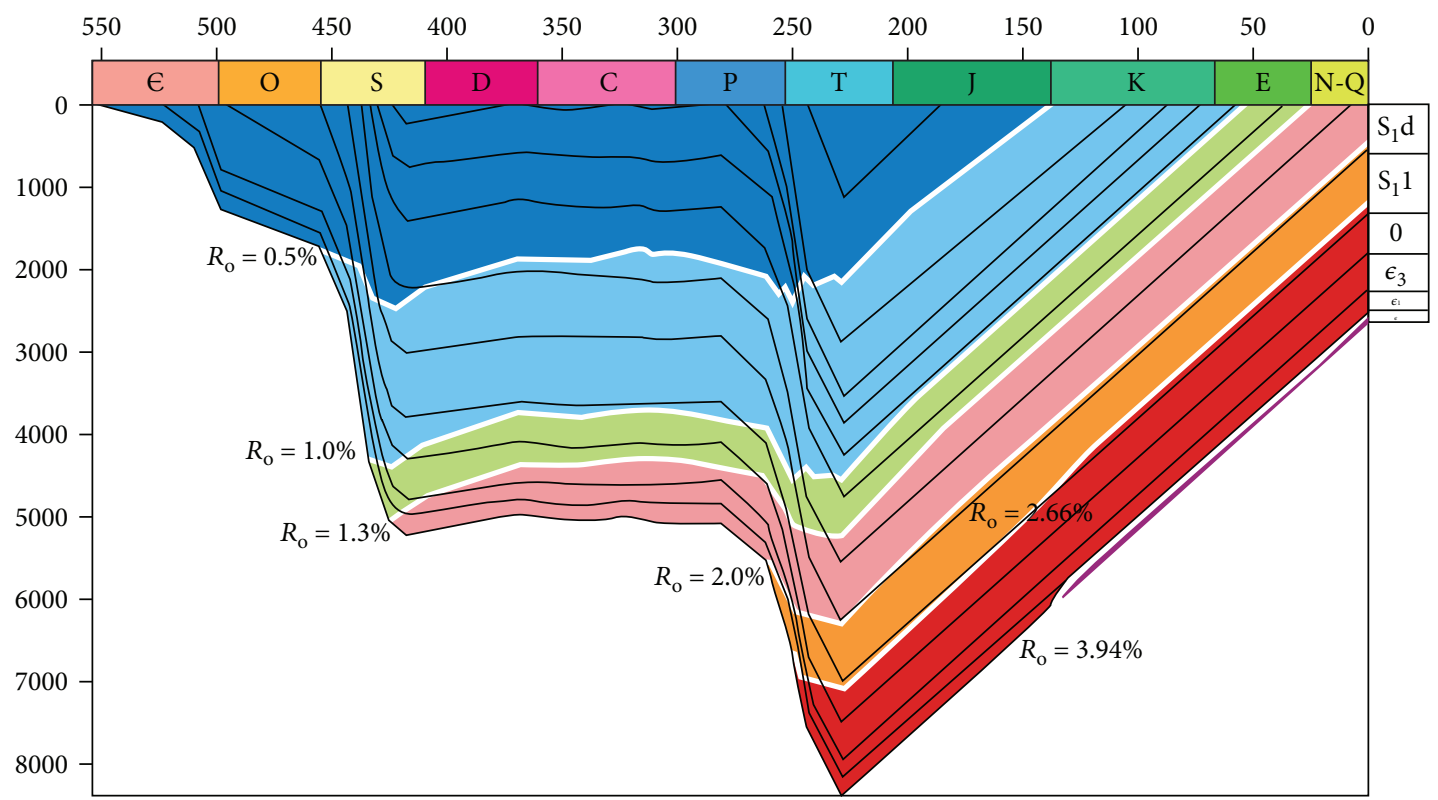

FIgURE 11: The burial history and the thermal evolution history of Jiangye-1 in Xiuwu Basin. See Figure 1 for the well location (modified from Li et al. [45]).
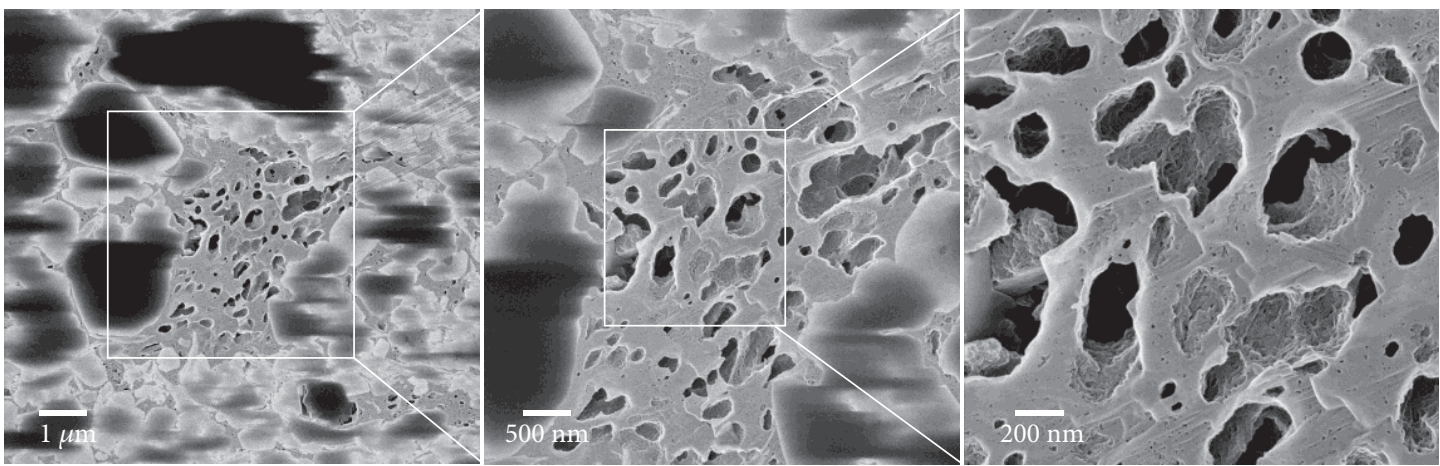

(a)
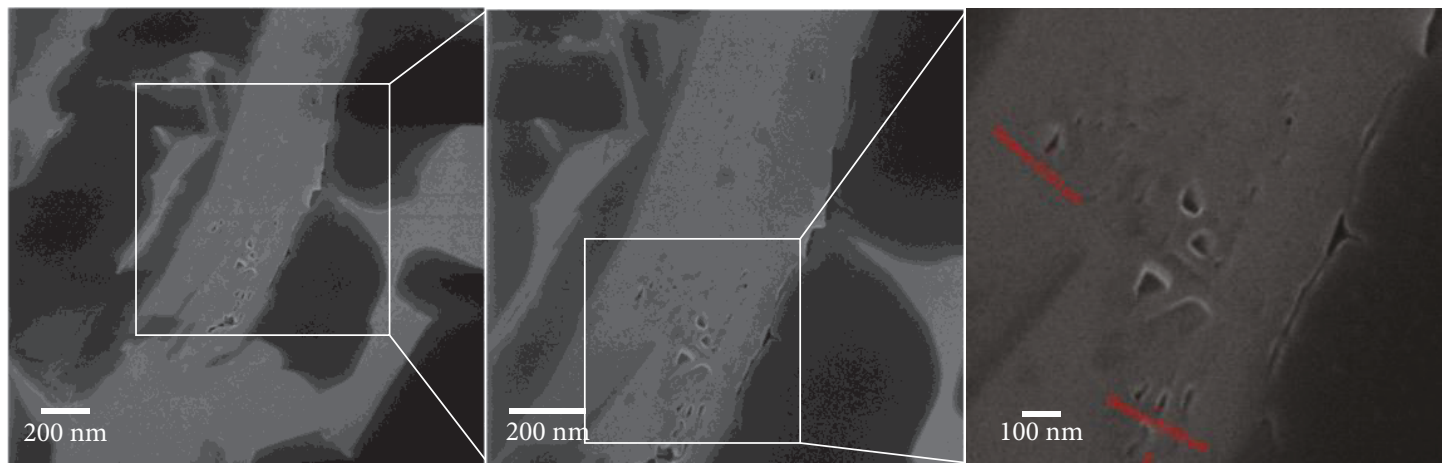

(b)

FIGURE 12: FIB-HIM photos of organic-rich shale: (a) the lower Silurian Longmaxi shale in Jiaoye-1, Jiaoshiba Play (depth: 2402 m, TOC: $4.44 \%, R_{\mathrm{o}}: 2.58 \%$ ) (from Wang et al. [13]) and (b) the lower Silurian Wangyinpu shale in Jiangye-1, Xiuwu Basin (depth: $2402 \mathrm{~m}, \mathrm{TOC}$ : $\left.11.27 \%, R_{\mathrm{o}}: 3.8 \%\right)$. See Figure 1 for the well locations.

the lower Cambrian shale gas play in Xiuwu Basin, this paper takes two shale gas exploration wells, Jiangye-1 and Jiangye-2, as examples. After determining the detailed shale gas composition through the on-field gas component analysis, stable nitrogen isotopes were applied to identify the sources of the nitrogen. Then the overburden permeability tests in different directions reflected the existence of migration pathways and the FIB-HIM photos revealed the negative impact of overmaturity on organic pores, which, combined with the comprehensive analysis of the geological settings, the 


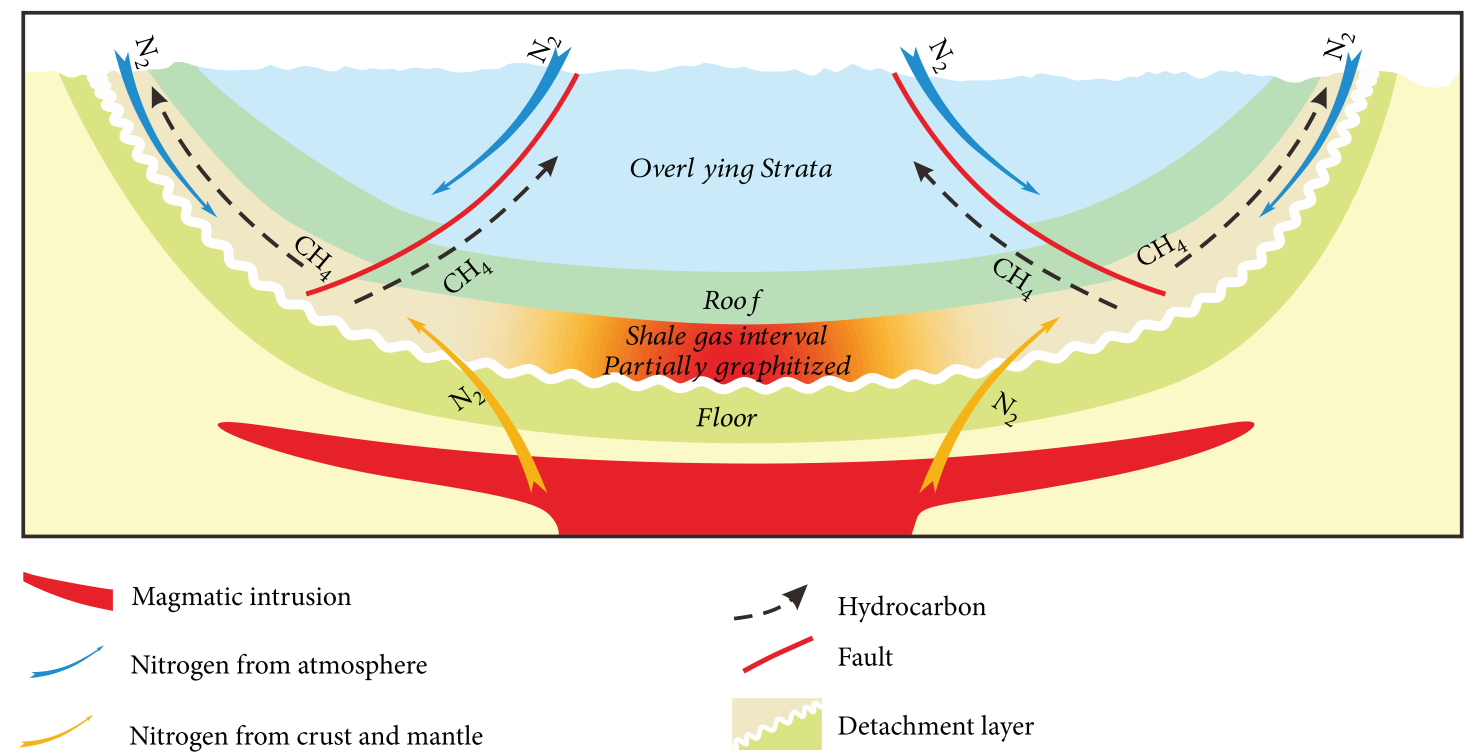

FIGURE 13: An explanation model for the destruction of shale gas reservoirs and the nitrogen concentration in the study area.

description of cores and outcrop, the interpretation of seismic section, and the history of thermal and tectonic evolution reveal the causes of the phenomenon which was the result of the effects of the effective pathway network, the magmatic activities, and the consequent overmaturity of organic matter. The explanation model of the destruction of shale gas reservoir in study area was summarized, and the conclusion was drawn as follows:

(i) With the gas component analysis on the field, it revealed that the nitrogen accounts for $80 \mathrm{vol} . \%$ in the lower Cambrian shale gas. The value of $\delta^{15} \mathrm{~N}$ ranges from $-0.8 \%$ to $0 \%$, which reflects that the nitrogen is mainly from the atmosphere and the deep crust and upper mantle according to the summary of previous works

(ii) Effective network of migration pathways partly led to the high content of nitrogen. The shale bedding surface and the detachment layer at the bottom of the lower Cambrian compose of the lateral pathways to atmosphere. In vertical, massively developed trust faults damaged the quality sealing, forming the pathway network with the lateral ones

(iii) The frequent magmatic activities in the Jurassic brought nitrogen from deep crust and upper mantle and caused the organic matter highly overmatured to the graphitization stage, consequently reducing the storage capability and accelerating the methane loss, which increased the relative content of nitrogen in shale gas

\section{Data Availability}

Some of the data are contained in a published source cited in the References. All the data in this article is accessible to readers.

\section{Disclosure}

An earlier version of this study was presented as an abstract in GSA Annual Meeting in Indianapolis, Indiana, USA-2018.

\section{Conflicts of Interest}

There are no conflicts of interest with respect to the results of this paper.

\section{Authors' Contributions}

Yizhou Huang and Kun Zhang contributed equally to this work.

\section{Acknowledgments}

Thanks are due to all the financings supporting the research, which are the National Science and Technology Major Project, the Science Foundation of the Ministry of Land and Resources of China, the National Natural Science Foundation of China, the Performance Incentive and Guidance of Chongqing Scientific Research Institute, and the Sinopec Key Laboratory of Shale Oil/Gas Exploration and Production Technology. Also, thanks are due to all coauthors who worked with me through the whole research.

\section{References}

[1] J. B. Curtis, "Fractured shale-gas systems," AAPG Bulletin, vol. 86, no. 11, pp. 1921-1938, 2002.

[2] S. L. Montgomery, D. M. Jarvie, K. A. Bowker, and R. M. Pollastro, "Mississippian Barnett shale, Fort Worth basin, north-central Texas: gas-shale play with multi-trillion cubic foot potential," AAPG Bulletin, vol. 89, no. 2, pp. 155-175, 2005. 
[3] D. N. Warlick, "Gas shale and CBM development in North America," Oil \& Gas Financial Journal, vol. 3, no. 11, pp. 1-5, 2006.

[4] D. Dong, Y. Wang, X. Li et al., "Breakthrough and prospect of shale gas exploration and development in China," Natural Gas Industry B, vol. 3, no. 1, pp. 12-26, 2016.

[5] T. Guo, "Key geological issues and main controls on accumulation and enrichment of Chinese shale gas," Petroleum Exploration and Development, vol. 43, no. 3, pp. 349-359, 2016.

[6] H.-Y. Zhu, X. C. Jin, J. C. Guo, F. C. An, Y. H. Wang, and X. . Lai, "Coupled flow, stress and damage modelling of interactions between hydraulic fractures and natural fractures in shale gas reservoirs," International Journal of Oil, Gas and Coal Technology, vol. 13, no. 4, p. 359, 2016.

[7] H. Zhu, J. Deng, X. Jin, L. Hu, and B. Luo, "Hydraulic fracture initiation and propagation from wellbore with oriented perforation," Rock Mechanics and Rock Engineering, vol. 48, no. 2, pp. 585-601, 2015.

[8] G. Xusheng, H. Dongfeng, W. Zhihong, L. Yuping, and W. Xiangfeng, "Discovery and exploration of Fuling shale gas field," China Petroleum Exploration, vol. 21, no. 3, pp. 24-37, 2016.

[9] W. Xiangfeng, Z. Zhengbao, W. Qingbo, L. Zhujiang, Z. Min, and Z. Hui, "Comprehensive evaluation on geological conditions of the shale gas in Upper Ordovician Wufeng Formation-Lower Silurian Longmaxi Formation in Dingshan area, Qijiang, Southeastern Sichuan," Geological Review, vol. 63, no. 1, pp. 153-164, 2017.

[10] X. Tang, Z. Jiang, Z. Li et al., "The effect of the variation in material composition on the heterogeneous pore structure of high-maturity shale of the Silurian Longmaxi formation in the southeastern Sichuan Basin, China," Journal of Natural Gas Science and Engineering, vol. 23, pp. 464-473, 2015.

[11] X. Tang, Z. Jiang, S. Jiang, P. Wang, and C. Xiang, "Effect of organic matter and maturity on pore size distribution and gas storage capacity in high-mature to post-mature shales," Energy \& Fuels, vol. 30, no. 11, pp. 8985-8996, 2016.

[12] X. Tang, Z. Jiang, S. Jiang, L. Cheng, and Y. Zhang, "Characteristics and origin of in-situ gas desorption of the Cambrian Shuijingtuo Formation shale gas reservoir in the Sichuan Basin, China," Fuel, vol. 187, pp. 285-295, 2017.

[13] P. Wang, Z. Jiang, L. Chen et al., "Pore structure characterization for the Longmaxi and Niutitang shales in the Upper Yangtze Platform, South China: evidence from focused ion beamHe ion microscopy, nano-computerized tomography and gas adsorption analysis," Marine and Petroleum Geology, vol. 77, pp. 1323-1337, 2016.

[14] P. Wang, Z. Jiang, W. Ji et al., "Heterogeneity of intergranular, intraparticle and organic pores in Longmaxi shale in Sichuan Basin, South China: evidence from SEM digital images and fractal and multifractal geometries," Marine and Petroleum Geology, vol. 72, pp. 122-138, 2016.

[15] L. Chen, Z. Jiang, K. Liu, J. Tan, F. Gao, and P. Wang, "Pore structure characterization for organic-rich Lower Silurian shale in the Upper Yangtze Platform, South China: a possible mechanism for pore development," Journal of Natural Gas Science and Engineering, vol. 46, pp. 1-15, 2017.

[16] L. Chen, Z. Jiang, K. Liu et al., "Effect of lithofacies on gas storage capacity of marine and continental shales in the Sichuan Basin, China," Journal of Natural Gas Science and Engineering, vol. 36, pp. 773-785, 2016.
[17] K. Zhang, Z. Jiang, L. Yin et al., "Controlling functions of hydrothermal activity to shale gas content-taking lower Cambrian in Xiuwu Basin as an example," Marine and Petroleum Geology, vol. 85, pp. 177-193, 2017.

[18] K. Zhang, Z. Jiang, X. Xie et al., "Lateral percolation and its effect on shale gas accumulation on the basis of complex tectonic background," Geofluids, vol. 2018, Article ID 5195469, 11 pages, 2018

[19] Q. Y. Liu, L. Tao, H. Y. Zhu, Z. D. Lei, S. Jiang, and J. D. McLennan, "Macroscale mechanical and microscale structural changes in Chinese Wufeng shale with supercritical carbon dioxide fracturing," SPE Journal, vol. 23, no. 3, pp. 691-703, 2018.

[20] W. Zhao, J. Li, T. Yang, S. Wang, and J. Huang, "Geological difference and its significance of marine shale gases in South China," Petroleum Exploration and Development, vol. 43, no. 4, pp. 547-559, 2016.

[21] L.-Y. Cheng, Z.-Q. Yong, T.-Y. Wang, N. Lan, J.-Y. Yu, and B. Den, "Evaluation index of shale gas preservation for Niutitang Formation in the strong transformation zone," Natural Gas Geoscience, vol. 26, no. 12, pp. 2408-2416, 2015.

[22] X. Guo, D. Hu, Y. Li, Z. Wei, X. Wei, and Z. Liu, "Geological factors controlling shale gas enrichment and high production in Fuling shale gas field," Petroleum Exploration and Development, vol. 44, no. 4, pp. 513-523, 2017.

[23] G. Zhai, Y. Wang, S. Bao et al., "Major factors controlling the accumulation and high productivity of marine shale gas and prospect forecast in southern China," Earth Science, vol. 42, no. 7, pp. 1057-1068, 2017.

[24] W.-W. Liu, J.-C. Tian, X.-B. Lin, J.-N. Shi, C.-Y. Yang, and S.-F. Peng, "Characteristics and significance of mineral compositions in lower Cambrian black shale from Xiuwu Basin, Jiangxi, China," Journal of Chengdu University of Technology (Science \& Technology Edition), vol. 42, no. 1, pp. 90-97, 2015.

[25] F. Pang, S. J. Bao, S. M. Ren, S. Li, C. Tong, and L. Zeng, "Shale gas accumulation conditions and favorable areas of the Lower Cambrian in Xiuwu Basin," Journal of Northeast Petroleum University, vol. 38, no. 5, pp. 23-30, 2014.

[26] W. Qin, Q. Han, and J. Wang, "Shale gas reservoiring condition analysis in Xiuwu Basin," Energy Research and Management, vol. 3, no. 1, pp. 46-49, 2013.

[27] G. Wang, Y. Ju, and K. Han, "Early Paleozoic shale properties and gas potential evaluation in Xiuwu Basin, western Lower Yangtze Platform," Journal of Natural Gas Science and Engineering, vol. 22, pp. 489-497, 2015.

[28] W.-W. Jiao, S.-X. Wang, L.-J. Cheng, Q.-Y. Luo, and G.-J. Fang, "The reason of high nitrogen content and low hydrocarbon content of shale gas from the Lower Cambrian Niutitang Formation in southeast Chongqing," Natural Gas Geoscience, vol. 28, no. 12, pp. 1882-1890, 2017.

[29] G. He, "Geological characteristics of Lower Cambrian Shale in Xiuwu Basin," in Annual Meeting of Chinese Geoscience Union, vol. 10, pp. 132-134, Beijing, China, 2014.

[30] C. Anding, "Nitrogen as an index of oil-gas preservation conditions in marine strata," Petroleum Geology \& Experiment, vol. 27, no. 1, pp. 85-89, 2005.

[31] J. Chen and Y. Zhu, "The origin of molecular nitrogen in natural gas and geochemical characters of molecular nitrogen in natural gas from east part of Tarim Basin," Natural Gas Geoscience, vol. 14, no. 3, pp. 172-176, 2003. 
[32] J. He, W. Yan, and J. Cui, "Nitrogen gas source tracking and distinguishing in margin basins, northern South China Sea," Marine Origin Petroleum Geology, vol. 17, no. 3, pp. 85-89, 2012.

[33] J. Li, Z. Li, D. Wang et al., "Geochemical characteristics and $\mathrm{N}_{2}$ source of nitrogen riched natural gas in Tarim Basin," Acta Petrolei Sinica, vol. 34, no. S1, pp. 102-111, 2013.

[34] K. H. Xiao, H. Chen, Y. J. Wo, Y. Zhou, and Y. X. Zhang, "Impact of tectonic evolution on Paleozoic and Mesozoic petroleum systems in Jianghan plain," Oil \& Gas Geology, vol. 26, no. 5, pp. 688-693, 2005.

[35] F. F. Guo, J. Y. Kang, J. F. Sun, J. Z. Lu, and X. P. Wang, “Tectonic evolution and hydrocarbon accumulation model for marine strata in Jianghan Basin," Lithologic Reservoirs, vol. 22, no. 1, pp. 23-29, 2010.

[36] Z. Feng, Y. Peng, and Z. Jin, "Lithofacies paleogeography of the Cambrian in South China," Journal of Palaeogeography, vol. 3, no. 1, pp. 1-14, 2001.

[37] J. M. Yang, F. Yi, and L. Hou, "Genesis and petro-geochemical characteristics of the lower cambrian black shale series in the southeast of chongqing and tts adjacent area," Acta Mineralogica Sinica, vol. 24, no. 3, pp. 286-291, 2004.

[38] X. Qi, Q. Hu, and X. Yi, "Shale gas exploration prospect of lower Cambrian Wangyinpu formation in Xiuwu basin," China Mining Magazine, vol. 24, no. 10, pp. 102-107, 2015.

[39] L. F. Mei, D. F. Deng, C. B. Shen, and Z. Q. Liu, “Tectonic dynamics and marine hydrocarbon accumulation of Jiangnan-Xuefeng uplift," Geological Science and Technology Information, vol. 31, no. 5, pp. 85-93, 2012.

[40] P. Wang, Z. Jiang, B. Han et al., "Reservoir geological parameters for efficient exploration and development of Lower Cambrian Niutitang Formation shale gas in South China," Acta Petrolei Sinica, vol. 39, no. 2, pp. 152-162, 2018.

[41] B. M. Krooss, R. Littke, B. Müller, J. Frielingsdorf, K. Schwochau, and E. F. Idiz, "Generation of nitrogen and methane from sedimentary organic matter: implications on the dynamics of natural gas accumulations," Chemical Geology, vol. 126, no. 3-4, pp. 291-318, 1995.

[42] Z. Zeng, "Genetic type of nitrogen gas in sedimentary basins in China," Natural Gas Geoscience, vol. 13, no. 3/4, pp. 29-33, 2002.

[43] Q. Liu, W. Liu, and B. M. Krooss, "Advances in nitrogen geochemistry of natural gas," Natural Gas Geoscience, vol. 17, no. 1, pp. 119-124, 2006.

[44] Y. Wo, Y. Zhou, and K. Xiao, "The burial history and models for hydrocarbon generation and evolution in the marine strata in Southern China," Sedimentary Geology and Tethyan Geology, vol. 27, no. 3, pp. 94-100, 2007.

[45] Y. Li, Z. Jiang, W. Liu et al., "The effect of the tectonic thermal evolution history to gas content of Lower Cambrian Shales at Xiuwu Basin," Journal of Engineering Science and Technology Review, vol. 16, no. 34, pp. 44-51, 2016.

[46] H. Nie, S. Bao, B. Gao et al., "A study of shale gas preservation conditions for the Lower Paleozoic in Sichuan Basin and its periphery," Earth Science Frontiers, vol. 19, no. 3, pp. 280294, 2012.

[47] H. Nie, Z. Jin, R. Bian, and W. Du, "The "source-cap hydrocarbon-controlling" enrichment of shale gas in Upper Ordovician Wufeng Formation-Lower Silurian Longmaxi Formation of Sichuan Basin and its periphery," Acta Petrolei Sinica, vol. 37, no. 5, pp. 557-571, 2016.
[48] F. Zhou, Hydrocarbon Accumulation and Petroleum Formation in the Northern Margin of Jiangnan Uplift, China University of Geosciences, 2006.

[49] M. E. Curtis, B. J. Cardott, C. H. Sondergeld, and C. S. Rai, "Development of organic porosity in the Woodford Shale with increasing thermal maturity," International Journal of Coal Geology, vol. 103, pp. 26-31, 2012.

[50] W. Ji, Y. Song, Z. Jiang et al., "Fractal characteristics of nano-pores in the Lower Silurian Longmaxi shales from the Upper Yangtze Platform, South China," Marine and Petroleum Geology, vol. 78, pp. 88-98, 2016.

[51] W. Ji, Y. Song, Z. Jiang, X. Wang, Y. Bai, and J. Xing, “Geological controls and estimation algorithms of lacustrine shale gas adsorption capacity: a case study of the Triassic strata in the southeastern Ordos Basin, China," International Journal of Coal Geology, vol. 134-135, pp. 61-73, 2014.

[52] S.-F. Wang, Z.-Y. Zhang, D.-Z. Dong et al., "Microscopic pore structure and reasons making reservoir property weaker of Lower Cambrian Qiongzhusi shale, Sichuan Basin, China," Natural Gas Geoscience, vol. 27, no. 9, pp. 1619-1628, 2016.

[53] W. Zhao, T. Jing, X. Xiong, B. Wu, and Y. Zhou, "Graphitization characteristics of organic matter in marine-facies shale," Geological Science and Technology Information, vol. 37, no. 2, pp. 183-191, 2018.

[54] Y. Wang, D. Dong, X. Cheng, J. Huang, S. Wang, and S. Wang, "Electric property evidences of carbonification of organic matters in marine shales and its geologic significance: a case study of the Lower Cambrian Qiongzhusi shale in the southern Sichuan Basin," Natural Gas Industry B, vol. 1, no. 2, pp. 129-136, 2014. 

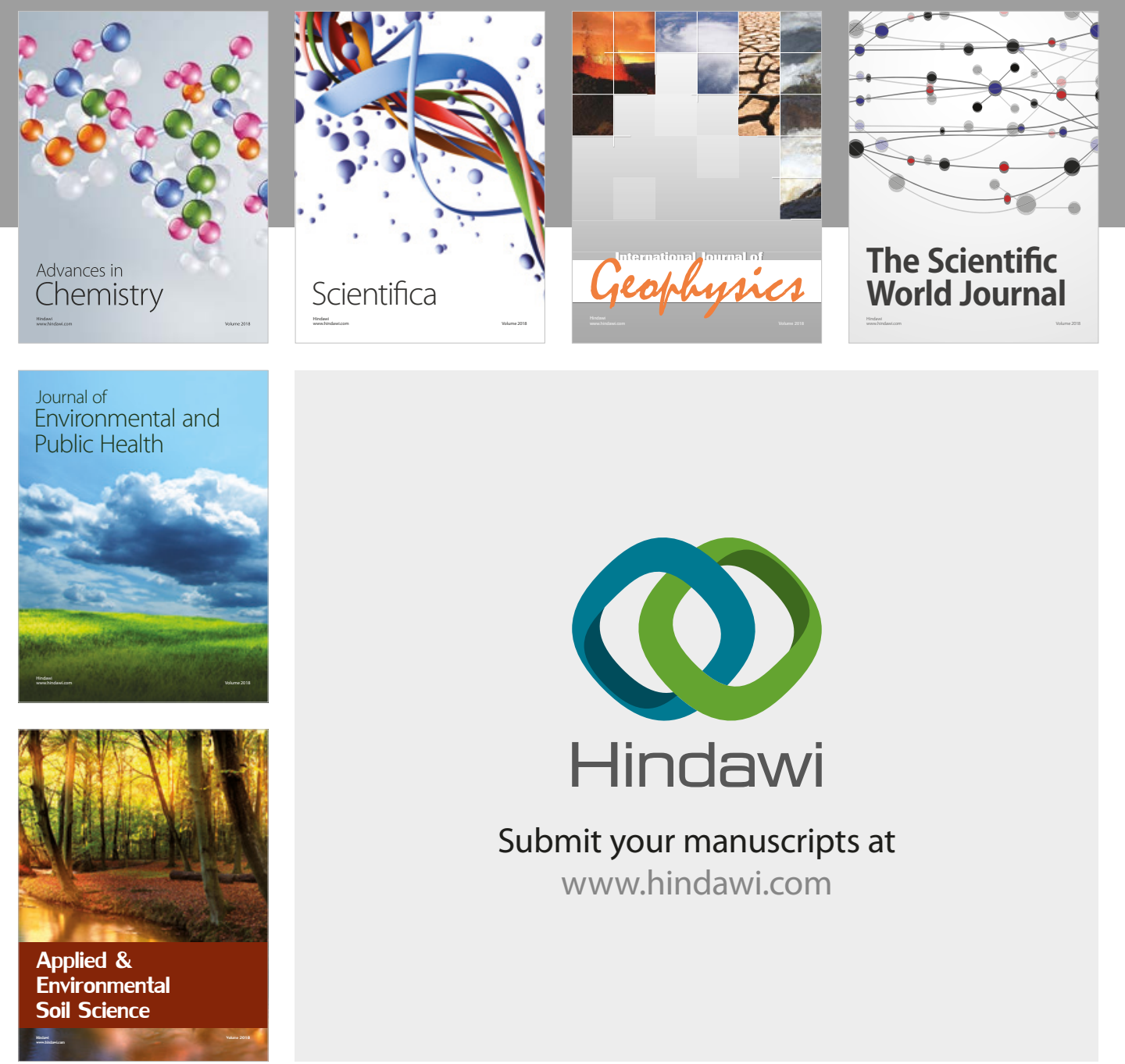

The Scientific

\section{World Journal}
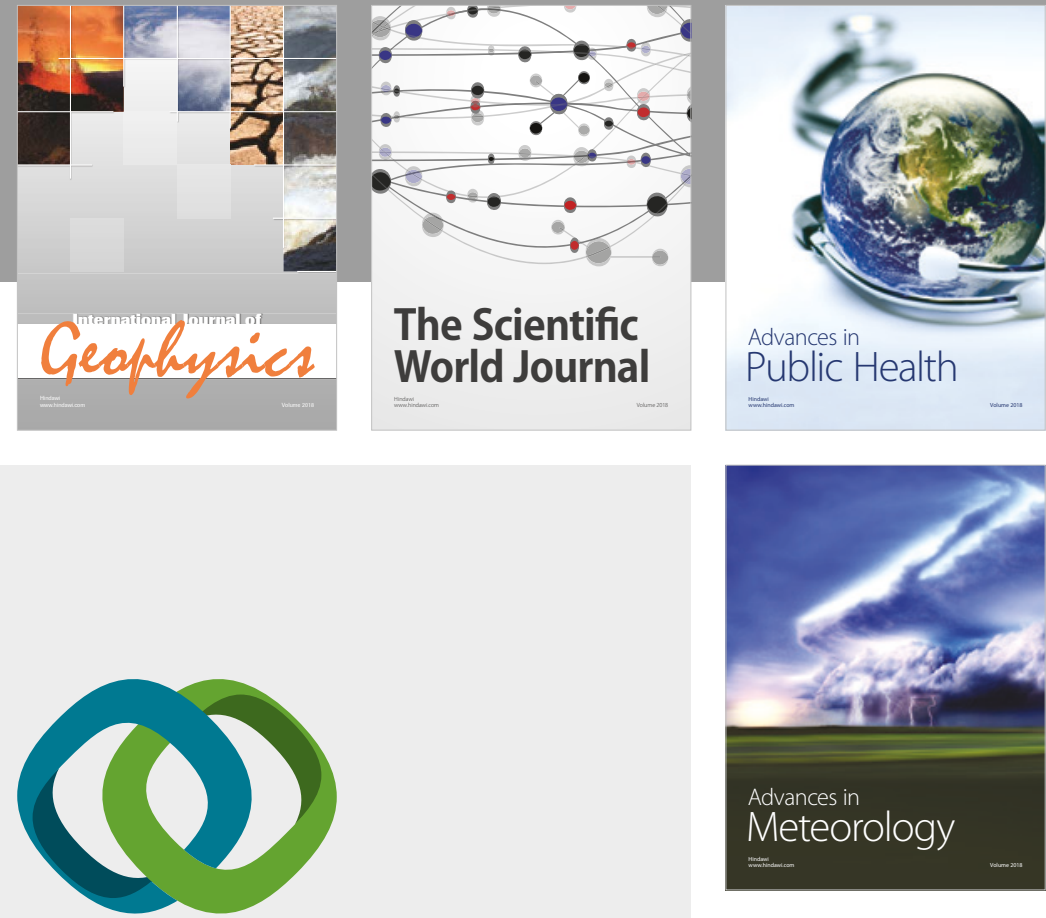

Advan

Public Health

\section{Hindawi}

Submit your manuscripts at

www.hindawi.com
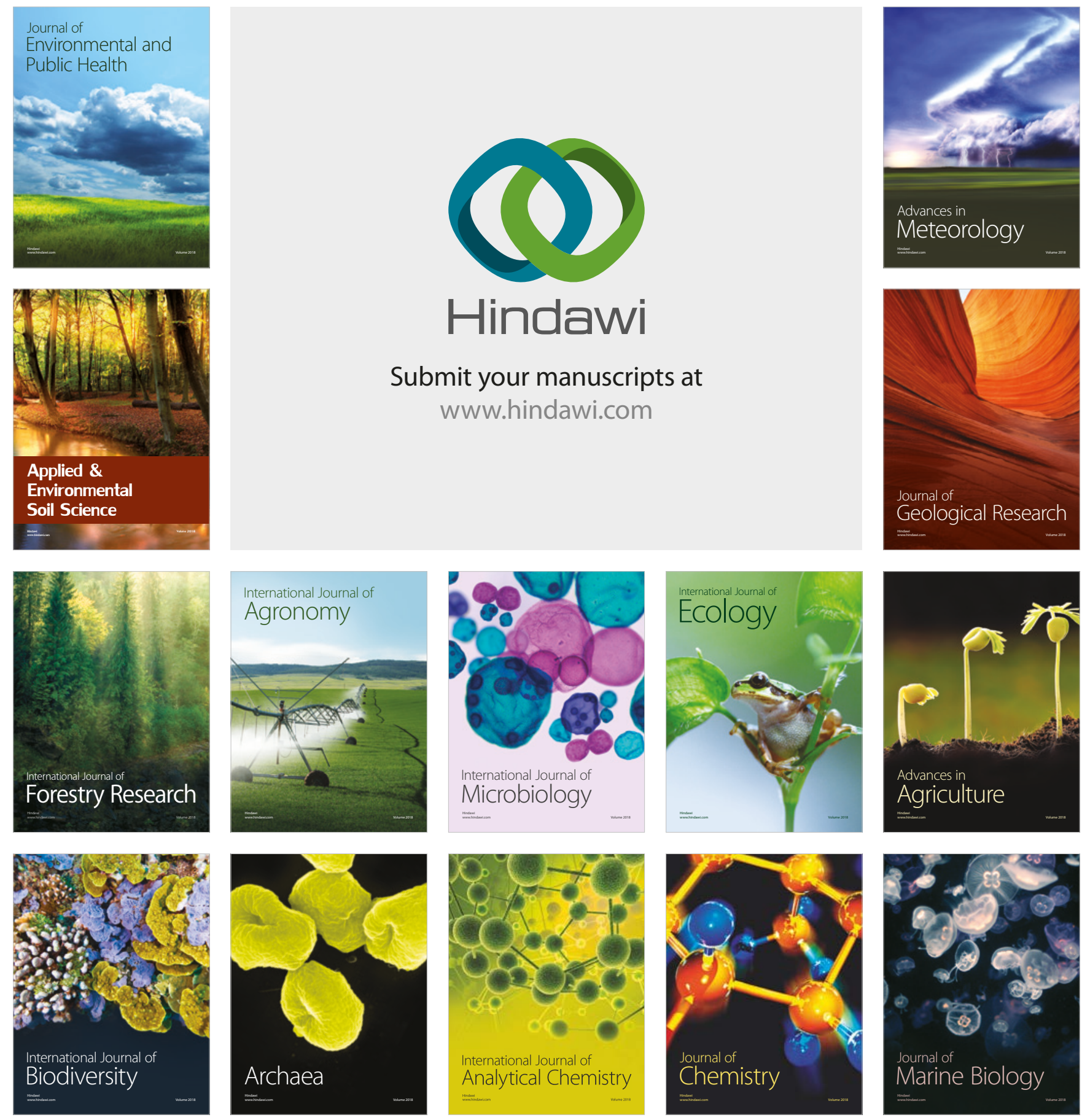